\title{
Research
}

\section{Oak Persistence in Mediterranean Landscapes: The Combined Role of Management, Topography, and Wildfires}

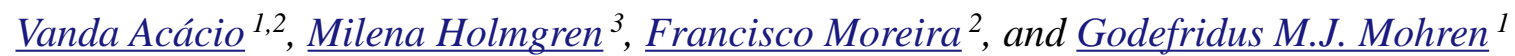

\begin{abstract}
Mediterranean ecosystems have been shaped by a history of human and ecological disturbances. Understanding the dynamics of these social-ecological systems requires an understanding of how human and ecological factors interact. In this study, we assess the combined role of management practices and biophysical variables, i.e., wildfire and topography, to explain patterns of tree persistence in a cork oak (Quercus suber L.) landscape of southern Portugal. We used face-to-face interviews with landowners to identify the management practices and the incentives that motivated them. We used aerial photographs and a Geographic Information System (GIS) to classify vegetation patch-type transitions over a period of 45 years (1958-2002) and logistic regression to explain such changes based on management and biophysical factors. The best model explaining vegetation transitions leading to cork oak persistence in the landscape included both biophysical and management variables. Tree persistence was more likely to occur on steeper slopes, in the absence of wildfires, and in the absence of understory management. We identified ecological, ideological, and economical barriers that preclude oak persistence and that are important to consider in implementing efficient environmental policies for adequate conservation and reforestation programs of Mediterranean cork oak landscapes.
\end{abstract}

Key Words: agroforestry system; alternative ecosystem state; Cistus ladanifer; land degradation; Mediterranean; Portugal; shrub encroachment; succession; Quercus suber; vegetation transition

\section{INTRODUCTION}

Mediterranean landscapes have long been shaped by a history of human management and natural disturbances (Aschmann 1973, Trabaud 1981, Conacher and Sala 1998). Understanding the dynamics of these ecosystems requires an understanding of how social and ecological factors interact, and how these interactions change over time (Lambin 2005, Perz 2007, Plieninger and Schaar 2008).

Since the 1960s, major socioeconomic changes in Mediterranean Europe have led to a gradual abandonment of traditional agriculture and stimulated rural exodus (Joffre et al. 1991, PintoCorreia 2000). Abandoned farmland was colonized by shrub and tree species, and a natural succession process from fallow to forest was observed in many locations (Mazzoleni et al. 2004). In the drier southernmost regions, however, succession appears arrested in early pioneer stages (Acácio et al. 2007, 2009, Costa et al. 2009).

The southwestern Iberian Peninsula has been shaped by a traditional agroforestry land use system where cork oak (Quercus suber L.), Holm oak (Quercus ilex L.), or a mixture of both, coexist with pastures and crops. The rural exodus of 50 years ago eliminated land ploughing and reduced herbivory in the understory of the oak savannas and forests (Pinto-Correia and Mascarenhas 1999, Alves et al. 2003, Pinto-Correia and Vos 2004). In the absence of human management, the usual pathway of natural succession in these agroforestry oak systems involves the gradual colonization of the understory by shrub species, i.e., pioneer Cistus shrubs, followed by other shrub communities like Arbutus and Erica, mixed with oak natural regeneration, which eventually can lead to forest recovery (Natividade 1950, Gonçalves 1991). However, several studies have reported decreasing oak density 
(Ferreira 2000, Vicente and Alés 2006, Vallejo et al. 2009), high oak seedling mortality (Direcção Geral das Florestas 1990, Montero et al. 1994), and lack of tree regeneration both in oak-dominated patches (Campos et al. 1998, Montero et al. 2000, Pulido and Díaz 2005), as well as in shrubland patches (Pons and Pausas 2006, Pausas et al. 2006).

Previous work in southern Portugal found that shrublands have expanded during the last 45 years at the expense of other vegetation patch-types, such as oak savannas and forests, particularly on southern slopes (Acácio et al. 2009). Although oak recruitment was observed in the years following the abandonment of agriculture and pastures, shrub encroachment progressed fast. In fact, since 1985 cork oak savannas and forests have been turning into shrublands at an increasing rate (Acácio et al. 2009). Initial cork oak recruitment in old fields after abandonment, followed by shrub encroachment, has also been observed in eastern Spain (Pons and Pausas 2006). Shrub encroachment can limit tree recruitment through multiple ecological mechanisms affecting tree seed dispersal, germination, and seedling survival (Acácio et al. 2007), and it is particularly severe under drier conditions or with frequent fires (Acácio et al. 2009).

Persistence of early successional stages may be intrinsically related to management decisions affecting the ecological processes involved in succession. Clearing of large areas for agriculture and pastures may eliminate nurse shrubs that facilitate tree seedling recruitment; it may also eliminate suitable seed dispersal sites and affect the habitats of the animal species responsible for seed dispersal. Also, livestock grazing, the second most common land use, contributes directly to seed and seedling predation (Herrera 1995, Pulido and Díaz 2002, Gómez et al. 2003, Leiva and Fernández-Alés 2003), preventing forest recovery. Management actions may interact with ecological processes and amplify limitations for seedling establishment, slowing down or preventing the natural process of succession even after management actions have been reversed. Although there is some understanding of the ecological mechanisms responsible for patch persistence in Mediterranean ecosystems (Fuentes et al. 1984, Gonçalves 1991, Montero et al. 1994, Puigdefábregas and Mendizabal 1998, Segura et al. 1998, Holmgren et al. 2000, Holmgren 2002, Holmgren and Scheffer
2001, Acácio et al. 2007), and the social factors involved (Pinto-Correia and Jorge 1996, Mazzoleni et al. 2004), the ways in which ecological and social mechanisms interact remains poorly studied and practically unknown (Rindfuss et al. 2004, Lambin 2005, Perz 2007). We hypothesize that management variables can play an important role in explaining persistence of cork oak trees and that they interact with topography and wildfire occurrence to explain the condition of arrested succession documented in cork oak landscapes of the Iberian Peninsula.

In this study, we assess the combined role of management practices and biophysical variables in explaining cork oak persistence in a 45-year period (1958-2002) and relate management decisions with landowner's perceptions. This long time frame allows evaluating tree persistence in a patchy landscape of forests, savannas, shrublands, and grasslands, where cork oak is the dominant tree species. We used a combination of aerial image analysis, databases with biophysical variables, and interviews with landowners to evaluate the role of ecological and management factors and the motivations behind local land management decisions.

\section{METHODS}

\section{Study area}

The study area covers 11,000 ha of the Serra do Caldeirão $\left(37^{\circ} 14^{\prime} \mathrm{N}, 7^{\circ} 56^{\prime} \mathrm{W}\right)$, a mountain ridge in the northeastern part of the Algarve province in southern Portugal. The climate is Mediterranean, with average annual temperature of $16.6^{\circ} \mathrm{C}$ (São Brás de Alportel meteorological station, INMG for the period 1958-1976, and SNIRH $a$ for the period 1980-2002), and average annual precipitation of approximately $900 \mathrm{~mm}$ (Barranco do Velho udometric station, INMG for the period 1958-1988, and SNIRH $b$ for the period 1989-2002). Altitudes range from 146 to 588 meters above sea level. Predominant soil type is schist lithosols (SROA 1970). Soils are shallow, with a topsoil of approximately $15 \mathrm{~cm}$, low fertility, and prone to erosion. Cork oak is the dominant tree species. This study area is one of the most continuous remnants of the southern Mediterranean cork oak landscapes of the Iberian Peninsula. 


\section{Historical background}

Before the 15th century, southern Portugal was covered with cork oak forests, which were mainly used by kings and nobility to hunt large game, for firewood, and for extensive grazing. Between the 15 th and the 17th centuries, the cork oak area in Portugal diminished substantially because of an increasing demand for wood for shipbuilding, agricultural land, and pastures. Cork began to be used for bottling wine after the 17th century, acquiring an increasing commercial value. From the 18th century onward, cork oak forests were gradually transformed into an agroforestry system exploited for cork, crops, and pastures (Mendes 2007). It is likely that the management of such agroforestry systems throughout the centuries also included protection of oak natural regeneration and artificial seeding or planting, to maintain cork production (Capelo and Catry 2007).

In the first half of the 20th century, traditional management of cork oak systems in the Iberian Peninsula included cork extraction, extensive grazing by pigs and sheep, and crop production. Shrub clearing and other land operations were done by manual labor and trees were exploited in unevenaged stands for natural regeneration (Soares et al. 1998). From 1929 until the beginning of the 1960s, most of the land in southern Portugal was cultivated for wheat, following a government policy known as The Wheat Campaign that strongly subsidized wheat production (Baptista 1993). During the 1950s, wheat cultivation expanded to less suitable lands with poor and shallow soils, such as oak forest lands, which tend to be more vulnerable to the detrimental effects of intensive cereal cultivation (Baptista 1993). At that time, most of the cork oak area in southern Portugal was exploited as an agroforestry system for cork, grazing, and cropping. The age-structure of stands included older trees from the 19th century and younger trees that had been planted at the onset of the 20th century, when large reforestation projects with cork oak took place in the south (Costa and Pereira 2007). Decades of The Wheat Campaign led to soil exhaustion (PintoCorreia and Vos 2004), elimination of cork oak natural regeneration, and the felling of many adult trees for cereal cultivation (Mendes 2007). Only forest areas located on steep slopes were not utilized as an agroforestry system because steepness made understory management for crop cultivation difficult or impossible.
Between the 1960s and 1970s, the country's agricultural working population decreased by about one third (Baptista 1993) because of important national and international socioeconomic changes, i.e., industrialization, immigration to cities, and emigration. After 1975, understory use had already been abandoned in the least productive lands and smaller properties in southern Portugal, including our study area, and cork was maintained as the single production component (Pinto-Correia and Mascarenhas 1999). At present, agriculture in our study area is only practiced for local family subsistence around the few scattered settlements and livestock has been reduced to only a few flocks of goats and sheep, approximately 500 animals, feeding mainly on fallow lands and shrublands (Pires 2000). Land holdings within the area are very fragmented and all under private tenure. Cork extraction is currently the main economic activity of the region, because it is the major economic asset of cork oak lands (Pereira 2007).

\section{Management and social variables}

Management and social data were derived from face-to-face interviews carried out by a single interviewer with local landowners. Landowners were defined as proprietors of the land although they may not necessarily live in the study area. Because there is no available landowner data for this region of Portugal, we selected landowners to be interviewed from the registration system of the Association of Forest Producers of Serra do Caldeirão (AFPSC). We were able to contact 20 landowners owning 31 parcels. This landowner sample is representative for the study region, because it includes about $20 \%$ of all members of AFPSC, who own about $10 \%$ of the land throughout the whole study area, according to data from AFPSC. The interviews included a combination of open-ended, qualitative questions along with closed, structured questions. Interviews were grouped in three main categories, each with questions covering several variables:

1. Land management between 1958 and 2002, using the following variables: 1) understory management, i.e., crops cultivation and/or livestock; 2) total livestock units; 3) livestock composition; 4) cutting adult cork oak trees; 5) shrub clearing; and 6) investments in land, including cork oak planting. 
2. Landowner profile, using the following variables: 1) age; 2) level of education; 3) type of management decisions, i.e., decisions made by owner or others; and 4) profession.

3. Individual perceptions: 1) factors related with forest cover change, using closed questions on cork oak natural regeneration and shrub encroachment, and open-ended questions on erosion, cork oak mortality, and wildfires; 2) open-ended questions on the main problems faced in local forest management; and 3) open-ended questions on what is missing for local forest management.

It is well known that when questions refer to an event that occurred long in the past, interviewees may not accurately recall their motivations and decisions and may even be confused as to which management strategy was implemented in each parcel (Rindfuss et al. 2004). To account for this, national historical events, such as elections of certain governments, etc., were used as dates to help the landowner remember the past management practices and circumstances around it. Therefore, the years 1975 and 1985 were used as key years to detect management changes because 1975 was the first year following the revolution that ended the dictatorship period in the country and also marked the end of the land abandonment period. Also, 1985 was an important political year followed by the adhesion of Portugal to the European Economic Community, today's European Union (EU), in 1986, with important land management changes. Management variables were derived from subquestions relating to the respective time periods and answers showed that management changes coincided within these specific periods for most of the farmers.

From the initial six land management variables (category 1), we derived a set of three variables summarizing the more relevant information for assessing vegetation patch-type transitions:

1) understory management before 1975 ; 2) tree cutting after 1975; 3) tree planting after 1985. Understory management existed only for the period before 1975. For all parcels except one, owners stopped understory use for livestock or crops after 1975. Understory management before 1975 was positively associated with the presence of livestock $\left(\chi^{2}=10.2, P=0.0014\right)$, and this latter variable resulted from a combination of the variables total livestock units and livestock composition, which were therefore excluded from further analysis. Understory management before 1975 was also positively associated with the variable shrub clearing $\left(\chi^{2}=21.6, P<0.001\right)$, so the latter variable was excluded from further analysis.

For all types of investments in land, such as acquiring machinery and equipment, pruning trees, improving forest road networks, and building water points, tree planting and cutting were the ones that had a higher visible impact in forest cover changes. Tree planting only took place after 1985 following EU subsidies. Adult cork oak trees were only cut after 1975 because of mortality.

\section{Collection of data on vegetation patch-type transitions}

Vegetation patch-type transitions were characterized using aerial photographs from 1958 and orthophotos, i.e., a rectified copy of an original aerial photograph, from 2002, thus covering a 45year period. Aerial photographs were previously scanned and then orthorectified and georeferenced with ENVI 3.4 (Research Systems 2001) to produce geometrically correct images and project them onto the same coordinate references as the digital orthophotos (Transverse Mercator projection, datum WGS84). Digital elevation models with a spatial resolution of eight meters were used for altitude coordinates (orthorectification process), and between 10 and 15 ground control points per photo were taken from the 2002-orthophoto for map coordinates (georeferentiation process). We obtained a RMS Error of about 10 meters. We overlaid a regular $0.5 \times 0.5 \mathrm{~km}$ grid of points over the entire study area, and selected all the points that were contained inside the parcels of the landowners who were interviewed. We selected 35 points from the 31 parcels (larger properties had more than one point) and photo interpreted on screen a $50 \mathrm{~m}$-radius circle (sampling unit) around each photographic point. Photointerpretation was performed on a photo-by-photo basis. The grid was created with ArcView GIS 3.2 (Environmental Systems Research Institute 1999) and laid over the aerial photographs and orthophotos (imported into the GIS as scanned images). For 1958 and 2002, each of the 35 sampling units was classified into one of four vegetation patch-types (Table 1). 
When more than one vegetation patch-type occurred in a sampling unit, it was classified based on the predominant type. Sampling units with only one kind of patch-type were predominant $(>50 \%$ of the total units) and when not, we could usually clearly assign one dominant class to each unit. We used tree cover percentage rather than tree density because in many cases it was not possible to count the number of trees on the photographs. Boundaries for forest cover (10\% and $30 \%$ of ground cover) follow the National Forest Inventory norms (Direcção Geral das Florestas 2001).

Before photo classification (2003) we visited the study area several times to familiarize ourselves with the different vegetation types and compare them with the patterns on the aerial photos of 2002. We estimated transitions between vegetation patchtypes by counting the number of sampling units of any vegetation patch-type that changed into any other between 1958 and 2002. Vegetation changes where there was maintenance or increase in tree cover were registered as presence of cork oak persistence; whereas patch-type transitions toward absence or decrease in tree cover were registered as absence of cork oak persistence (Table 2).

\section{Biophysical variables}

Three environmental variables were registered: slope, exposure, and wildfire occurrence. Slope determines soil depth and erosion risk, which in turn affect tree growth and survival. The exposure of a slope determines the amount of incident irradiance and therefore is strongly correlated with plant water stress, e.g., southern exposures are drier, and often plant survival. Wildfire directly affects tree and seedling mortality and indirectly influences several ecological processes involved in tree seedling recruitment and vegetation succession.

The topographical variables, slope and exposure, were derived from digital elevation models (Portuguese Military Geographic Institute, IGeoE) and stored as two ArcView GIS layers. We assigned one class of slope and exposure to each sampling unit based on the most common type. The slope categories were: low to medium (0-20\%); steep $(20-30 \%)$; very steep $(>30 \%)$. The exposure categories were: north facing slopes (including NW, $\mathrm{N}$, and $\mathrm{NE}$ ), south facing slopes (including $\mathrm{SW}, \mathrm{S}$, and SE) and others (E and W). Wildfire occurrence was available as spatially referenced and digitized data for every year between 1984 and 2002 (provided by the Tropical Research Institute for 1984-1989 unpublished data, and by the General Directorate of Forests for 1990-2002, http://www.a fn.min-agricultura.pt/portal/dudf/cartografia/cartografareas-ardidas-1990-2009). The limits of the burned area per year were stored as an ArcView GIS layer and overlaid with the sampling units to identify the sampling units that were affected by fire between 1984 and 2002. The maximum number of times a unit was affected by fire in this period was two.

\section{Statistical analyses}

Logistic regression (Hosmer and Lemeshow 2000) was used to model the influence of biophysical and management variables on oak tree persistence (coded as $1=$ presence $/ 0=$ absence) during the period 1958-2002. Because of the small sample size in the lower slope class, only 2 slope categories were considered, $\leq 30 \%$ and $>30 \%$. Exposure and wildfire were also considered as categorical variables.

To assess the relative importance of biophysical and management variables on the probability of cork oak persistence, we used an Information Theoretical Approach (ITA; Burnham and Anderson 2002). The ITA looks for simplicity and parsimony of several working hypotheses and is based on finding the strength of evidence of each model, for a set of candidate predictive models. The AIC adjusted for small samples $\left(\mathrm{AIC}_{\mathrm{c}}\right)$ was used as a measure of information loss of each candidate model, with the best fitting model having the lowest $\mathrm{AIC}_{\mathrm{c}}$ and the highest Akaike weight $\left(\mathrm{w}_{\mathrm{i}}\right)$. The latter measures the relative likelihood that a given model is the best one, given the data and the set of competing candidate models. $\mathrm{AIC}_{\mathrm{c}}$ differences $(\Delta \mathrm{i})$ between each model and the model with the smaller $\mathrm{AIC}\left(\mathrm{AIC}_{\text {min }}\right)$ can be used to assess the relative support for the different alternative models (Burnham and Anderson 2002, Rushton et al. 2004).

To avoid overfitting and finding spurious effects when working with small sample sizes, the number of candidate models should be small (Anderson 2008). Thus, we used stepwise regression as a way of keeping the number of candidate models low, relative to our sample size, prior to the ITA evaluation. In this sense, we did not use null hypothesis testing to compare models, but we used it to restrict the number of candidate models in our set to be evaluated by the IT approach. Overall, we 
Table. 1 Classification of vegetation patch-types.

\begin{tabular}{ll}
\hline \hline Vegetation patch-type & \multicolumn{1}{c}{ Description } \\
\hline Cork oak forests & $\begin{array}{l}\text { High cork oak (Quercus suber L.) density (more than 100-150 trees/ha) and a diverse } \\
\text { shrubby layer, e.g., Arbutus unedo, Viburnum tinus, Erica arborea, Pistacia lentiscus, } \\
\text { Rhamnus alaternus, Phillyrea latifolia; this class corresponds to a tree cover higher than } \\
30 \%\end{array}$ \\
Cork oak savannas & $\begin{array}{l}\text { Low cork oak density (less than } 100 \text { trees/ha) with sparse shrubs in the understory; this } \\
\text { class corresponds to a tree cover between } 10 \% \text { and } 30 \%\end{array}$ \\
Shrublands & $\begin{array}{l}\text { Dominated by Cistus ladanifer shrubs, pure or mixed with Ulex argenteus, Genista hirsuta, } \\
\text { and Lavandula stoechas shrubs; this class corresponds to a tree cover lower than } 10 \%\end{array}$ \\
Grasslands & $\begin{array}{l}\text { Dominated by cultivated croplands, semi-natural pastures, or fallow land; this class } \\
\text { corresponds to a tree cover lower than 10\% }\end{array}$ \\
\hline
\end{tabular}

built 12 models: a) separate models for each of the predictor variables (6 models); b) models for each set, i.e., biophysical and management, of variables (2 models); c) stepwise models, forward and backward stepwise selection yielded similar models, for each set (2 models); and d) stepwise models, forward and backward selection, pooling all 6 variables from both sets (2 models). The relative importance of each variable was estimated by summing the Akaike weights across all models that contained that variable (Burnham and Anderson 2002). Model fit and predictive performance of each model were evaluated through the likelihood ratio statistic (full model $\chi^{2}$ ) and by calculating the area under the receiver operating characteristics (AUC) curve (Pearce and Ferrier 2000).

\section{RESULTS}

\section{Land management and landowner's profile}

Before 1975, most landowners used their lands as an agroforestry system for cork, pastures, and crops (70\% of respondents at 26 sampling units). Herd sizes of mostly sheep and pigs varied between 50 and 100 animals per herd, which grazed on each landowner parcel, with an average parcel of 10 ha, but also throughout the study area. After 1975, adult dead trees were cut at 29 sampling units (about $80 \%$ of total sampling units) and after 1985, cork oak tree planting was carried out at 14 sampling units $(40 \%$ of all sampling units). All interviewees are responsible for the decisions and implementation of their own land management practices, however, only $10 \%$ work directly on the land, $50 \%$ are retired, and $40 \%$ have a different profession than land management. Most landowners were older than 60 years ( $60 \%$ of interviewees), and only one (5\% of interviewees) was younger than 45 years old. Half of the interviewees had only a primary school education and $20 \%$ were college-educated.

\section{Landowner' perceptions}

Table 3 shows the frequency, i.e., number and percentage, of landowner responses regarding the main causes of soil erosion, tree mortality, and fire, changes in natural regeneration, and changes in shrubland cover since 1960 . Table 4 shows direct quotations from landowners regarding difficulties and needs on local forest management.

For landowners, soil erosion was mostly caused by the use of disk harrowing, rippers, and heavy machinery $(21.2 \%)$, followed by heavy rains. However, opposite reasons such as cereal cultivation in the past and lack of cereal cultivation were also pointed out as responsible for soil erosion 
Table 2. Types of vegetation transitions (1958-2002) grouped into presence of cork oak (Quercus suber L.) persistence or absence of cork oak persistence (Fo: forest; Sa: savanna; Sr: shrubland; Gr: grassland)

\begin{tabular}{cccc}
\hline \hline & $\begin{array}{c}\text { Presence of cork oak persistence } \\
\text { (maintenance or increase in tree cover) }\end{array}$ & $\begin{array}{c}\text { Absence of cork oak persistence } \\
\text { (absence or decrease in tree cover) }\end{array}$ \\
\hline $\begin{array}{c}\text { Type of } \\
\text { transition }\end{array}$ & $\begin{array}{c}\text { \% from the total sampling units classified as } \\
\text { presence of oak persistence }\end{array}$ & $\begin{array}{c}\text { Type of } \\
\text { transition }\end{array}$ & $\begin{array}{c}\text { \% from the total sampling units classified as } \\
\text { absence of oak persistence }\end{array}$ \\
$\mathrm{Fo} \rightarrow \mathrm{Fo}$ & 48 & $\mathrm{Fo} \rightarrow \mathrm{Sr}$ & 33 \\
$\mathrm{Sa} \rightarrow \mathrm{Sa}$ & 13 & $\mathrm{Sa} \rightarrow \mathrm{Sr}$ & 17 \\
$\mathrm{Sa} \rightarrow \mathrm{Fo}$ & 13 & $\mathrm{Sa} \rightarrow \mathrm{Gr}$ & 8 \\
$\mathrm{Sr} \rightarrow \mathrm{Fo}$ & 9 & $\mathrm{Sr} \rightarrow \mathrm{Sr}$ & 17 \\
$\mathrm{Sr} \rightarrow \mathrm{Sa}$ & 4 & $\mathrm{Gr} \rightarrow \mathrm{Sr}$ & 17 \\
$\mathrm{Gr} \rightarrow \mathrm{Sa}$ & 13 & $\mathrm{Gr} \rightarrow \mathrm{Gr}$ & 8 \\
\hline
\end{tabular}

(15.2\% and $9.1 \%$ of total causes, respectively). We also found that $35 \%$ of interviewees perceived that soil erosion was not a problem at the study site. On the other hand, $7.7 \%$ of farmers perceived soil erosion as a cause of oak mortality (Table 3).

The landowners identified a long list of main causes to explain cork oak mortality but by far the most frequent one was disease $(24.4 \%$ of all responses corresponding to $95 \%$ of all interviewees). The disease to which landowners are referring is the one caused by the fungi Phytophthora cinnamomi, which has been correlated with cork oak decline in several recent studies (Moreira and Martins 2005). Perhaps surprisingly, lack of traditional land use that combines wheat cultivation and livestock, was mentioned as the second most frequent cause of cork oak mortality ( $15.4 \%$ of all responses corresponding to $60 \%$ of interviewees). Landowners further explained that wheat cultivation and livestock provided fertilizers and manure to the soil, and the lack of such management is responsible for cork oak mortality today. Drought and management changes from traditional manual labor to the use of disk harrowing and heavy machinery are the two next most frequent responses for cork oak mortality (12.8\% and 9\%, respectively; Table 3).

Most interviewees (80\%) considered that oak natural regeneration increased since 1960 after understory cultivation ceased, whereas $20 \%$ of the interviewees stated that natural regeneration has decreased since that date (Table 3). Most landowners stated that they do not protect natural regeneration during silvicultural interventions such as shrub clearing, which can lead to the destruction of seedlings. Landowners also claimed that the use of inadequate techniques, such as bad terrain preparation and insufficient supervision during the first years, in planting were responsible for low seedling survival rates. Furthermore, during the course of the interviews, several landowners stated that direct oak seeding should be used instead of planting because it would allow higher seedling survival, but EU programs have only been subsidizing planting operations. Two of those landowners included seeding with selected acorns and subsidies for seeding when asked about "what is missing for local forest management" (see Table 4). Interestingly, most interviewees $(80 \%)$ reported that Cistus shrublands have increased since 1960 and only one affirmed that shrubland area has decreased because of subsidized shrub clearing in the last decades. Three respondents stated that there were no changes in shrubland area (Table 3 ).

Cork oak mortality, including disease, and wildfires were pointed out as the two main difficulties for local forest management by $35 \%$ and $30 \%$ of all respondents, respectively (Table 4). Setting fire 
Table 3. Landowner's individual perceptions (frequency of responses). Total number of responses per question (in Q1, Q2, and Q3) is higher than number of interviewees (20) because each interviewee usually provided more than one response to each question.

\begin{tabular}{|c|c|c|c|}
\hline \multirow[t]{2}{*}{ Question asked } & \multirow[t]{2}{*}{ Response } & \multicolumn{2}{|c|}{$\begin{array}{l}\text { Frequency of } \\
\text { response }\end{array}$} \\
\hline & & Number & $\%$ \\
\hline $\begin{array}{l}\text { Q1. What are the main } \\
\text { causes of soil erosion } \\
\text { at the study area? } \\
\text { (open-ended) }\end{array}$ & $\begin{array}{l}\text { Lack of fertilizer and lack of cereal cultivation } \\
\text { Drought } \\
\text { Cereal cultivation in the past } \\
\text { Disk harrowing, use of rippers and heavy machinery } \\
\text { Heavy rains } \\
\text { Complete shrub clearing in steep terrains } \\
\text { Decreasing tree density } \\
\text { Wildfires } \\
\text { Total }\end{array}$ & $\begin{array}{l}3 \\
5 \\
5 \\
7 \\
6 \\
2 \\
1 \\
4 \\
33\end{array}$ & $\begin{array}{r}9.1 \\
15.2 \\
15.2 \\
21.2 \\
18.2 \\
6.1 \\
3.0 \\
12.1 \\
100\end{array}$ \\
\hline $\begin{array}{l}\text { Q2. What are the main } \\
\text { causes of cork oak } \\
\text { mortality at the study } \\
\text { area?(open-ended) }\end{array}$ & $\begin{array}{l}\text { Disease } \\
\text { Drought } \\
\text { Wildfires } \\
\text { Complete shrub clearing } \\
\text { Lack of traditional land use with wheat cultivation and livestock (lack of } \\
\text { fertilizer and manure) } \\
\text { Pesticides } \\
\text { Disk harrowing and ploughing, shrub clearing with heavy machinery } \\
\text { Less soil water } \\
\text { Old age of cork oak trees } \\
\text { Soil erosion } \\
\text { Pollution } \\
\text { Clayey soils } \\
\text { Inadequate human management } \\
\text { Total }\end{array}$ & $\begin{array}{l}19 \\
10 \\
5 \\
3 \\
12 \\
1 \\
7 \\
1 \\
1 \\
6 \\
5 \\
2 \\
6 \\
78\end{array}$ & $\begin{array}{c}24.4 \\
12.8 \\
6.4 \\
3.8 \\
15.4 \\
\\
1.3 \\
9.0 \\
1.3 \\
1.3 \\
7.7 \\
6.4 \\
2.6 \\
7.7 \\
100\end{array}$ \\
\hline $\begin{array}{l}\text { Q3. What are the main } \\
\text { causes of wildfires at } \\
\text { the study area? } \\
\text { (open-ended) }\end{array}$ & $\begin{array}{l}\text { Arson } \\
\text { Lack of shrub clearing and fuel management } \\
\text { Drought } \\
\text { Lack of firemen capacity: bad coordination among firemen during combat; } \\
\text { firemen lack forest fire fighting techniques and have bad knowledge of the } \\
\text { terrain } \\
\text { Negligence } \\
\text { Accidents } \\
\text { Total }\end{array}$ & $\begin{array}{l}19 \\
5 \\
3 \\
5\end{array}$ & $\begin{array}{c}52.8 \\
13.9 \\
8.3 \\
13.9\end{array}$ \\
\hline $\begin{array}{l}\text { Q4. How did cork oak } \\
\text { natural regeneration } \\
\text { change since } 1960 ? \\
\text { (closed) }\end{array}$ & $\begin{array}{l}\text { Increased } \\
\text { Decreased } \\
\text { Total }\end{array}$ & $\begin{array}{c}16 \\
4 \\
20\end{array}$ & $\begin{array}{c}80.0 \\
20 \\
100\end{array}$ \\
\hline $\begin{array}{l}\text { Q5. How did } \\
\text { shrubland area change } \\
\text { since } 1960 ? \\
\text { (closed) }\end{array}$ & $\begin{array}{l}\text { Increased } \\
\text { Decreased } \\
\text { No changes } \\
\text { Total }\end{array}$ & $\begin{array}{c}16 \\
1 \\
3 \\
20\end{array}$ & $\begin{array}{c}80.0 \\
5.0 \\
15.0 \\
100\end{array}$ \\
\hline
\end{tabular}




\section{Table 4. Management difficulties and needs identified by landowners. Table shows direct quotations from} landowners.

\begin{tabular}{|c|c|c|}
\hline $\begin{array}{l}\text { Interview } \\
\text { Number }\end{array}$ & Main difficulties for local forest management & What is missing? \\
\hline 1 & Properties are too small to invest & Government subsidies \\
\hline 2 & Topography of the landscape & More shrub clearing to prevent wildfires \\
\hline 3 & Wildfires, cork oak disease & (no answer) \\
\hline 4 & $\begin{array}{l}\text { Wildfires, lack of machines, high costs of shrub } \\
\text { clearing }\end{array}$ & $\begin{array}{l}\text { Roads, machines, seeding with selected acorns, prescribed burning in } \\
\text { the winter }\end{array}$ \\
\hline 5 & Wildfires and disease & Manpower \\
\hline 6 & $\begin{array}{l}\text { Cork oak mortality, lack of cadastre, small } \\
\text { property }\end{array}$ & $\begin{array}{l}\text { Landowner cooperatives and concerted management, scientific } \\
\text { research; environmental instruments are too rigid concerning fuel } \\
\text { management }\end{array}$ \\
\hline 7 & $\begin{array}{l}\text { Cork oak mortality, long time for subsidies } \\
\text { payment; acorn production has been decreasing }\end{array}$ & $\begin{array}{l}\text { More communication between landowners and researchers, livestock } \\
\text { to feed on the grass and shrubs (fuel management) }\end{array}$ \\
\hline 8 & Wildfires & (no answer) \\
\hline 9 & (no answer) & (no answer) \\
\hline 10 & Lack of land profitability, land abandonment & (no answer) \\
\hline 11 & $\begin{array}{l}\text { Lack of land profitability, decreasing cork } \\
\text { production because of disease }\end{array}$ & $\begin{array}{l}\text { Compensations for restrictions from environmental instruments such } \\
\text { as Natura 2000, cadastre }\end{array}$ \\
\hline 12 & $\begin{array}{l}\text { Bureaucracy (e.g., long time to get an } \\
\text { authorization to cut a dead cork oak) }\end{array}$ & $\begin{array}{l}\text { There are no subsidies for seeding, (which is more successful than } \\
\text { plantations), landowners cooperatives, more decision making power } \\
\text { for Associations of Forest Producers }\end{array}$ \\
\hline 13 & $\begin{array}{l}\text { Cork oak mortality (still without a cure for the } \\
\text { disease), market competition with plastic stoppers }\end{array}$ & (no answer) \\
\hline 14 & $\begin{array}{l}\text { Lack of forest fire fighting techniques; too much } \\
\text { bureaucracy for investments with subsidies and } \\
\text { long time waiting for money }\end{array}$ & $\begin{array}{l}\text { Subsidies for livestock (which is good for fuel management and } \\
\text { fertilizing the soil); improvement of inspection }\end{array}$ \\
\hline 15 & $\begin{array}{l}\text { Cork oak mortality, decreasing cork production, } \\
\text { money has to be invested before receiving } \\
\text { subsidies }\end{array}$ & Find a cure for the cork oak disease \\
\hline 16 & Cork oak mortality & Manpower, people working the land and living there \\
\hline 17 & $\begin{array}{l}\text { Land abandonment, lack of profitability of small } \\
\text { landowners }\end{array}$ & Forest management, faster payment of subsidies and less bureaucracy \\
\hline 18 & Small property and land fragmentation & $\begin{array}{l}\text { Livestock for fuel management, landowners cooperatives, multiple-use } \\
\text { forest management }\end{array}$ \\
\hline 19 & Wildfires & Less taxes for managers and businesses; incite production \\
\hline 20 & Wildfires & Landowner cooperation \\
\hline
\end{tabular}


intentionally was pointed out as the main reason for wildfires ( $52.8 \%$ of total responses), followed by lack of firemen capacity to fight forest fires and lack of fuel management (both with $13.9 \%$ of total responses; see Table 3). Bureaucracy, i.e., the long wait for subsidies payment and for authorization to cut a dead cork oak tree (20\%), small property size, and lack of land profitability (both with 15\%) were the next most frequent answers. Many other issues were quoted as problems for local forest management, including decreasing acorn and cork production, land abandonment, lack of cadastre, and market competition with plastic stoppers (Table 4).

Landowner cooperatives, subsidies for seeding, livestock, and compensation for restrictions from environmental programs, livestock for fuel management, manpower, and communication between researchers and landowners were quoted as the most important needs for local forest management (Table 4). Five landowners did not respond when asked about what is missing.

\section{Determinants of tree persistence: management or biophysical variables?}

Vegetation patch-type transitions indicating presence of tree persistence were observed at 23 sampling units (65.7\% of all units) mostly because of persistence of forest and savannas (48\% and 13\% from the total sampling units registered as presence of oak persistence, respectively) and transitions from savannas to forests $(13 \%$ from the total sampling units registered as presence of oak persistence). Vegetation patch-type transitions indicating absence of tree persistence were observed at 12 sampling units (34.3\% of all units) mostly because of changes from forests, savannas, and grasslands to shrublands $(33 \%, 17 \%$, and $17 \%$ from the total sampling units registered as absence of oak persistence, respectively), and shrublands persistence (17\% from the total sampling units registered as absence of oak persistence; see Table 2).

The best model for tree persistence, i.e., persistence of forest and savannas, transitions from any patchtype to forests, and transitions from shrublands and grasslands to savannas, during the period 1958-2002, included both biophysical, i.e., slope and wildfire, and management variables, i.e., understory management and tree planting, and had an Akaike weight of 0.76 (model 1 in Table 5).
According to Anderson (2008), models within $\Delta_{\mathrm{i}}$ up to four have substantial support, thus the second model $\left(\Delta_{\mathrm{i}}=2.304\right)$ is also considered an alternatively good fit to the data. This second model (Akaike weight of 0.24) is similar to the first one but with the exclusion of slope. All remaining models have much higher $\Delta_{\mathrm{i}}$ and residual Akaike weights. The evidence for the first two models is expressed by summing their Akaike weights, showing that they represent an approximate $99 \%$ confidence set, i.e., we have $99 \%$ confidence that these two statistical models represent the best fit among the set of models compared. In these two models, wildfire occurrence, understory management before 1975, and cork oak planting were the most important variables. These three variables were equally important, each with an Akaike weight of 0.99. Slope followed in importance (Akaike weight $=0.76)$ whereas the remaining variables were not relevant for the models (Akaike weights $<0.01$ ). The two best models showed that cork oak persistence was more likely in areas where understory management, using livestock or cultivation, and cork oak plantings were never carried out, in steeper slopes and in the absence of wildfires (Table 5).

\section{DISCUSSION}

\section{Cork oak persistence best explained by both management and biophysical variables}

The analysis of alternative statistical models shows that cork oak persistence is better explained by models including both biophysical and management variables than by those based only on one set of variables alone. Previous work at the study area had identified two ecological variables, wildfire and exposure, as the two most important biophysical variables explaining patch-type transitions (Acácio et al. 2009). Our results now clearly demonstrate that vegetation changes are better explained by also taking management variables into account. Cork oaks are most likely to persist in areas where understory management, using livestock or cultivation, and cork oak plantings were never carried out, especially on steeper slopes and in the absence of wildfires. This indicates that management is a significant driver of vegetation change and a significant variable to explain patchtype transitions and tree persistence patterns in this Mediterranean landscape. 
Table 5. Statistical models for tree persistence. For each model, the table shows the predictor variables entering the model (remaining variables did not enter), respective direction of association (positive + or negative -) with the response variable (presence of cork oak persistence), the AICc value, AICc differences $(\Delta \mathrm{i})$ and Akaike weights (wi), and model fit (full model $\chi^{2}$ ) and area under curve (AUC \pm s.e.). Models are ordered by increasing $\Delta \mathrm{i}$, with the best model having $\Delta \mathrm{i}=0$ (model 1 ) and the worst model having $\Delta \mathrm{i}=29.0$ (model 12). The type of model is also coded according to the method used: (a) separate models for each variable, (b) models for each set of biophysical and management variables, (c) stepwise models for each set of biophysical and management variables, (d) stepwise models with the whole set of variables. Codes for management variables: underst= understory management pre 1975; cuttree= tree cutting post 1975; afforest= tree planting post 1985.

\begin{tabular}{|c|c|c|c|c|c|c|c|c|c|c|c|}
\hline \multirow[b]{2}{*}{ Model } & \multicolumn{6}{|c|}{ Variables } & \multirow[b]{2}{*}{$\mathrm{AIC}_{\mathrm{c}}$} & \multirow[b]{2}{*}{$\Delta_{\mathrm{i}}$} & \multirow[b]{2}{*}{$\mathrm{w}_{\mathrm{i}}$} & \multirow[b]{2}{*}{$\chi^{2}$} & \multirow[b]{2}{*}{ AUC } \\
\hline & aspect & slope & fire & underst & cuttree & afforest & & & & & \\
\hline $1 \mathrm{~d}$ & & + & - & - & & - & 22.618 & 0.000 & 0.759 & 34.45 & $0.98 \pm 0.019$ \\
\hline $2 \mathrm{~d}$ & & & - & - & & - & 24.922 & 2.304 & 0.240 & 29.41 & $0.95 \pm 0.035$ \\
\hline $3 c$ & & & & - & & - & 37.062 & 14.444 & 0.001 & 14.71 & $0.83 \pm 0.069$ \\
\hline $4 \mathrm{~b}$ & & & & - & - & - & 38.583 & 15.965 & 0.000 & 15.75 & $0.85 \pm 0.066$ \\
\hline $5 \mathrm{c}$ & & + & - & & & & 39.933 & 17.315 & 0.000 & 11.84 & $0.80 \pm 0.084$ \\
\hline 6 a & & & & - & & & 40.265 & 17.647 & 0.000 & 9.11 & $0.69 \pm 0.087$ \\
\hline $7 \mathrm{a}$ & & & - & & & & 41.612 & 18.994 & 0.000 & 7.76 & $0.73 \pm 0.097$ \\
\hline $8 a$ & & & & & & - & 43.947 & 21.329 & 0.000 & 5.43 & $0.70 \pm 0.096$ \\
\hline $9 \mathrm{~b}$ & $-(S)^{\dagger}$ & + & - & & & & 44.481 & 21.863 & 0.000 & 12.59 & $0.81 \pm 0.080$ \\
\hline $10 \mathrm{a}$ & & + & & & & & 45.902 & 23.284 & 0.000 & 3.47 & $0.66 \pm 0.100$ \\
\hline $11 \mathrm{a}$ & & & & & - & & 48.278 & 25.660 & 0.000 & 1.01 & $0.56 \pm 0.100$ \\
\hline $12 \mathrm{a}$ & $-(\mathrm{S})^{\dagger}$ & & & & & & 51.661 & 29.043 & 0.000 & 0.12 & $0.52 \pm 0.103$ \\
\hline
\end{tabular}

${ }^{\dagger}$ less probability of tree persistence in southern exposures

\section{The role of management}

The fact that tree persistence was found to be more likely in areas where understory management had not occurred in the past can be explained in several ways. In southern Portugal, decades of intensive wheat cultivation and grazing pressure under oak savannas and forests led to severe soil fertility loss, still evident today (Natividade 1950, Oliveira 1955, Gonçalves 1991, Pinto-Correia and Vos 2004). Agroforesty practices in southern Spain had similar consequences (Montero et al. 1994). Intensive understory cultivation and grazing reduce perennial vegetation cover, increasing water and soil nutrients losses by water run-off and soil erosion that lead to soil degradation (Lima et al. 2000). Additionally, trampling by grazing herds causes soil compaction, which reduces water infiltration and further contributes to soil degradation (Pulido and Díaz 2002). Poor, degraded soils and higher insolation in nonvegetated sites make conditions for seedling establishment very difficult and thus halt tree 
persistence and recruitment. These positive feedbacks can maintain semiarid ecosystems in persistent states of low biomass (Westoby et al. 1989, Rietkerk and van de Koppel 1997, Holmgren and Scheffer 2001).

We also found that absence of tree persistence and transitions toward shrublands were more likely where cork oak planting had taken place, which seems a contradictory result at a first glance. However, cork oak plantations in the Algarve province have registered very low survival rates, especially on drier southern exposures (Lima et al. 2000). Inadequate planting techniques have been pointed out as a major reason for poor seedling and sapling recruitment, such as inadequate terrain preparation and shrub management and poor monitoring during the first years (Lima et al. 2000). Also, the low genetic quality of the reproductive material used in many cork oak reforestation projects in Portugal has been identified as a contributing cause of low reforestation success (Almeida et al. 2006). In Spain, oak plantings also suffer from high mortality rates because of summer drought (Alloza and Vallejo 1999, Castro et al. 2002).

Furthermore, initial vegetation clearings for reforestation projects not only destroy existing seedlings but eliminate nurse plants that can facilitate seedling recruitment (Castro et al. 2002). As a result, unvegetated sites are quickly invaded by Cistus shrubs that compete with the remaining seedlings for soil water and nutrients, increasing oak mortality and subsequently decreasing tree persistence.

\section{The role of biophysical variables}

Cork oak persistence was most likely to occur in the absence of wildfires. Frequent fires or intense ones can kill adult cork oak trees especially when burning occurs immediately after cork extraction (Cabezudo et al. 1995, Pausas 1997, Moreira et al. 2007), which takes place in the summer months, coincident with the start of the wildfire season in Mediterranean Europe. Because the abandonment of traditional agroforestry led to shrub colonization and the accumulation of dead wood, former cork oak systems experienced an increase in wildfire hazard (Pausas and Vallejo 1999, Piussi and Farrell 2000, Pardini et al. 2004). Higher fire frequency increases the loss of soil fertility by accelerating erosion
(Pardini et al. 2004). Moreover, because colonizing Cistus shrubs are well adapted to very poor soils (Gonçalves 1991) and rely on fire to spread their seeds, this triggers the conditions for a positive feedback where cork oak recruitment is difficult and the system remains in an arrested early successional stage dominated by pyrophytic Cistus shrubs.

The best statistical model also shows that cork oak persistence was more likely to occur on steeper slopes, although slope presents a lower Akaike weight than understory management and wildfire. This is probably because on these slopes, forests were less vulnerable to human interventions, especially ploughing, which is practically impossible on very steep slopes.

\section{Landowner's perceptions behind management decisions}

From an ecological perspective, the landowners' perceptions on the ecological conditions of these systems and the mechanisms that explain them appear perhaps surprising: 15\% of the landowners believe that the absence of traditional land use combining wheat cultivation and livestock is one of the main causes of oak mortality; $9 \%$ believe that the lack of wheat cultivation is in fact responsible for soil erosion; and $35 \%$ of them believe that soil erosion is not a problem.

Landowners are likely to have a landscape preference for agroforestry systems because this is the type of traditional landscape they perceive as appropriate and they may find it difficult to accept its transformation (Gómez-Limón and de Lucío Fernández 1999). Therefore, they deny the existence of a problem, such as soil erosion. This ideological barrier (Scheffer et al. 2000) can prevent landowners from choosing adequate management practices, such as adequate techniques for shrub clearing or protection of natural regeneration, which could certainly contribute to increase cork oak persistence in the study area.

Landowner behavior within the region is also conditioned by the perception that their holding is too small and that further improvement through investment would not pay dividends. On the other hand, some types of land operations are subsidized by the EU, which facilitates management actions that may not be appropriate. For instance, although landowners believe that seeding is the best method 
for cork oak artificial reforestation, they chose to use planting operations instead because these are economically subsidized. In fact, subsidies are included on the list of needs for local forest management. Subsidies play an important role in management decisions and can contribute to further degradation of tree cover in some cases (PintoCorreia and Vos 2004). In our statistical analysis, planting was a significant variable contributing to absence of tree persistence and was also identified by many landowners as a problem.

\section{CONCLUSION}

Our results show that the dynamics of Mediterranean landscapes are better understood as coupled social-ecological systems requiring an integrated approach that combines interdisciplinary tools from ecological and social sciences. We found that land management, i.e., intensive understory use and inadequate planting operations, in combination with biophysical factors, i.e., wildfire and slope, facilitated shrub encroachment and prevented tree persistence or recovery between 1958 and 2002. It is likely that oak savannas and forests lost resilience, as a result of past land uses damaging soil and vegetation, and are currently additionally threatened by more frequent wildfires. As a result, natural succession appears halted into a pioneer state dominated by Cistus shrublands where cork oak forest recovery can become very difficult even through assisted reforestation. Our study highlights a series of ecological, ideological, and economical barriers that contribute to this process. If the cork oak systems are to be maintained, forest regeneration should be stimulated by addressing those barriers in a concerted way.

Responses to this article can be read online at: http://www.ecologyandsociety.org/voll5/iss4/art40/ responses/

\section{Acknowledgments:}

This research was funded by the Portuguese Foundation for Science and Technology (Fundação para a Ciência e a Tecnologia), fellowship number SFRH/BD/5008/2001 to V. Acácio. M. Holmgren thanks the Dutch NWO Meervoud Programme (836.05.021). We thank the Associação dos Produtores Florestais da Serra do Caldeirão
(APFSC) for kindly providing the information on land property. We also thank: the Portuguese Military Geographic Institute, the Portuguese Geographic Institute, and the National Pulp Industry Association for kindly providing the photographic material; Rute Palmeiro, Susana Pereira, Tiago Dias, and Miguel Porto who helped with photo interpretation work; João Carreiras and Filipa Marques who assisted with ENVI and ArcView software. Information on burned areas between 1984 and 1989 was kindly provided by Maria José Vasconcelos (project "Spatio-temporal fire patterns in Portugal 1984-2003. Impacts, risk assessment, and fuel dynamics", POCTI/ AGG/44942/2002, Tropical Research Institute, IICT, Lisbon, Portugal). Information on burned areas between 1990 and 2002 was kindly provided by the General Directorate of Forests (DGRF Direcção Geral das Florestas). Special thanks to Frances Westley for her suggestions on an earlier version of this manuscript.

\section{LITERATURE CITED}

Acácio, V., M. Holmgren, P. Jansen, and O. Schrotter. 2007. Multiple recruitment limitation causes arrested succession in Mediterranean cork oak systems. Ecosystems 10:1220-1230.

Acácio, V., M. Holmgren, F. Rego, F. Moreira, and G. M. J. Mohren. 2009. Are drought and wildfires turning Mediterranean cork oak forests into persistent shrublands? Agroforestry Systems 76:389-400.

Alloza, J. A., and R. Vallejo. 1999. Relación entre las características meteorológicas del año de plantación y los resultados de las repoblaciones. Ecología 13:173-187.

Almeida, M. H., T. Sampaio, M. J. Lourenço, H. Merouami, F. Costa e Silva, A. M. Nunes, M. R. Chambel, M. Branco, C. Faria, M. C. Varela, and J. S. Pereira. 2006. Influência da qualidade dos materiais de reprodução na reflorestação com sobreiro. Pages 173-176 in M. Espejo, M. Martin, C. Mato, and F. J. Mesias, editors. Gestión ambiental y económica del ecosistema dehesa en la Península Ibérica. Junta de Extremadura, Consejería de Infraestructuras y Desarrollo Tecnológico, Mérida, Spain. 
Alves, A. L., N. S. Carvalho, S. Silveira, S. CastelBranco, J. P. Marques, Z. Costa, A. L. Horta, editors. 2003. O abandono da actividade agrícola. Grupo de Trabalho Agro-Ambiental. Acção 2.2.1. Ministério da Agricultura, Desenvolvimento Rural e Pescas, Lisboa, Portugal.

Anderson, D., editor. 2008. Model based inference in the life sciences. Springer, Fort Collins, Colorado, USA.

Aschmann, H. 1973. Man's impact on the several regions with Mediterranean climates. Pages 363-371 in F. Di Castri and H. A. Mooney, editors. Mediterranean type ecosystems. Origin and structure. Springer-Verlag Berlin, Berlin, Germany.

Baptista, F. 1993. A política agrária do Estado Novo. Edições Afrontamento, Lisboa, Portugal.

Burnham, K.P., and D. R. Anderson. 2002. Model selection and multi-model inference: a practical information-theoretic approach. Second edition. Springer-Verlag, New York, New York, USA.

Cabezudo, B., A. P. La Torre, and J. M. Nieto. 1995. Regeneración de un alcornocal incendidado en el Sur de España (Istán, Málaga). Acta Botanica Malacitana 20:143-151.

Campos, P., M. Díaz, and F. J. Pulido. 1998. Las dehesas arboladas. Un equilibrio necesario entre explotación y conservación. Quercus 147:31-35.

Capelo, J., and F. Catry. 2007. A distribuição do sobreiro em Portugal. Pages 107-113 in J. Sande Silva, editor. Os Montados. Muito para além das árvores. Árvores e Florestas de Portugal 3, Público, Comunicação Social SA, Fundação LusoAmericana para o Desenvolvimento, Lisboa, Portugal.

Castro, J., R. Zamora, J. A. Hódar, and J. M. Gómez. 2002. The use of shrubs as nurse plants: a new technique for reforestation in Mediterranean mountains. Restoration Ecology 10:297-305.

Conacher, A. J., and M. Sala, editors. 1998. Land degradation in Mediterranean environments of the world. Nature and extent, causes and solutions. John Wiley \& Sons, Chichester, UK.
Costa, A., and H. Pereira. 2007. Montados e sobreirais: uma espécie, duas perspectivas. Pages 17-37 in J. Sande Silva, editor. Os Montados. Muito para além das árvores.. Árvores e Florestas de Portugal 3. Público, Comunicação Social SA, Fundação Luso-Americana para o Desenvolvimento, Lisboa, Portugal.

Costa, A., H. Pereira, M. Madeira. 2009. Landscape dynamics in endangered cork oak woodlands in Southwestern Portugal (1958-2005). Agroforestry Systems 77:83-96.

Direcção Geral das Florestas, editor. 1990. Inventário florestal do sobreiro. Estudos $e$ Informacão n. ${ }^{\circ}$ 300. Direcção Geral das Florestas, Lisboa, Portugal.

Direcção Geral das Florestas, editor. 2001. Inventário florestal nacional: Portugal continental. 3. ${ }^{a}$ revisão 1995-1998. Relatório final. Direcção Geral das Florestas, Lisboa, Portugal.

Environmental Systems Research Institute, editor. 1999. ArcView GIS 3.2. Environmental Systems Research Institute, Redlands, California, USA.

Ferreira, F. 2000. The cork oak condition in Portugal. Pages 121-130 in T. Oszako and C. Delatour, editors. Recent advances on oak health in Europe. Forest Research Institute, Warsaw, Poland.

Fuentes, E. R., R. D. Otaiza, M. C. Alliende, A. J. Hoffmann, and A. Poiani. 1984. Shrub clumps of the Chilean matorral vegetation: structure and possible maintenance mechanisms. Oecologia 62:405-411.

Gómez J.-M., D. García, and R. Zamora. 2003. Impact of vertebrate acorn-and seedling-predators on a Mediterranean Quercus pyrenaica forest. Forest Ecology and Management 180:125-134.

Gómez-Limón, J., and J. V. de Lucío Fernández. 1999. Changes in use and landscape preferences on the agricultural-livestock landscapes of the central Iberian Peninsula (Madrid, Spain). Landscape and Urban Planning 44:165-175.

Gonçalves, J. 1991. Fitocenoses espontâneas dos sobreirais alentejanos: factores ambientais $e$ 
dinâmica da vegetação associada a condições de mortalidade das árvores. Relatório Final do Curso de Eng. ${ }^{\circ}$ Silvicultor. Instituto Superior de Agronomia, Universidade Técnica de Lisboa, Lisboa, Portugal.

Herrera, J. 1995. Acorn predation and seedling production in a low-density population of cork oak (Quercus suber L.). Forest Ecology and Management 76:197-201.

Holmgren, M. 2002. Exotic herbivores as drivers of plant invasion and switch to ecosystem alternative states. Biological Invasions 4:25-33.

Holmgren, M., and M. Scheffer. 2001. El Niño as a window of opportunity for the restoration of degraded arid ecosystems. Ecosystems 4:151-159.

Holmgren, M., A. M. Segura, and E. R. Fuentes. 2000. Limiting mechanisms in the regeneration of the Chilean matorral. Plant Ecology 147:49-57.

Hosmer, D. W., and S. Lemeshow. 2000. Applied logistic regression. Second edition. John Wiley \& Sons, New York, New York, USA.

Instituto Geográfico do Exército (IGeoE). Modelos digitais do Terreno. MDT (Intergraph GRD). Base de Dados Geográfica (Série M888, escala 1/25 000). Instituto Geográfico do Exército, Portugal.

Instituto Nacional de Meteorologia e Geofisica (INMG). 1958-1988. Anuários Climatológicos de Portugal. 1958-1988. Lisboa, Portugal.

Joffre, R., B. Hubert, and M. Meuret. 1991. Les systèmes agro-sylvo-pastoraux méditerranéens: enjeux et réflexions pour une gestion raisonnée. Dossier MAB 10, UNESCO, Paris, France.

Lambin, E. F. 2005. Conditions for sustainability of human-environment systems: information, motivation and capacity. Global Environmental Change 15:177-180.

Leiva, M. J., and R. Fernández-Alés. 2003. Postdispersive losses of acorns from Mediterranean savannah-like forests and shrublands. Forest Ecology and Management 176:265-271.
Lima, M. B., D. A. F. Bernardo, M. E. B. Madeira e Madeira, J. M. Graça, A. L. T. Félix, F. Rita, S. I. G. Custódio, J. J. L. M. Varela, I. C. C. P. da Silva, and J. E. Bouça, editors. 2000. Sistemas agrários tradicionais no Algarve - contributos para o seu estudo. Direcção Regional de Agricultura do Algarve, Faro, Portugal.

Mazzoleni, S., G. Di Pasquale, M. Mulligan, P. di Martino, and F. Rego, editors. 2004. Recent dynamics of the Mediterranean vegetation and landscape. John Wiley \& Sons, Chichester, UK.

Mendes, A. C. 2007. O sobreiro ao longo dos tempos. Pages 77-106 in J. Sande Silva, editor. Os montados. Muito para além das árvores. Árvores e Florestas de Portugal 3. Público, Comunicação Social SA, Fundação Luso-Americana para o Desenvolvimento, Lisboa, Portugal.

Montero, G., E. Torres, and I. Cañellas. 1994. Regeneración de alcornocales. Síntesis bibliográfica. Ecología 8:271-283.

Montero, G., A. San Miguel, and I. Cañellas. 2000. Systems of Mediterranean Silviculture: La Dehesa. Grafistaff. S.L., Madrid, Spain.

Moreira, F., I. Duarte, F. Catry, and V. Acácio. 2007. Cork extraction as a key factor determining post-fire cork oak survival in a mountain region of southern Portugal. Forest Ecology and Management 253:30-37.

Moreira, A. C., and M. S. Martins. 2005. Influence of site factors on the impact of Phytophthora cinnamomi in cork oak stands in Portugal. Forest Pathology 35:145-162.

Natividade, J. V. 1950. Subericultura. Ministério da Agricultura, Pescas e Alimentação, DirecçãoGeral das Florestas, Lisboa, Portugal.

Oliveira, A. F. L. 1955. Subsídios para o estudo da vegetação espontânea da Serra do Caldeirão (freguesia de Salir). Relatório final do curso de Eng. - Agrónomo. Instituto Superior de Agronomia, Universidade Técnica de Lisboa, Lisboa, Portugal.

Pardini, G., M. Gispert, and G. Dunjó. 2004. Relative influence of wildfire on soil properties and erosion processes in different Mediterranean 
environments in NE Spain. Science of the Total Environment 328:237-246.

Pausas, J. G. 1997. Resprouting of Quercus suber in NE Spain after fire. Journal of Vegetation Science 8:703-706.

Pausas, J. G., and V. R. Vallejo. 1999. The role of fire in European Mediterranean ecosystems. Pages 3-16 in E. Chuvieco, editor. Remote sensing of large wildfires in the European Mediterranean Basin. Springer-Verlag, Berlin, Germany.

Pausas, J. G., E. Ribeiro, S. G. Dias, J. Pons, and C. Beseler. 2006. Regeneration of a marginal Cork oak (Quercus suber) forest in the eastern Iberian Peninsula. Journal of Vegetation Science 17:729-738.

Pearce, J., and S. Ferrier. 2000. Evaluating the predictive performance of habitat models developed using logistic regression. Ecological Modelling 133:225-245.

Pereira, H. 2007. Cork: biology, production and uses. Elsevier Science, Amsterdam, The Netherlands.

Perz, S. G. 2007. Grand theory and contextspecificity in the study of forest dynamics: forest transition theory and other directions. The Professional Geographer 59:105-114.

Pinto-Correia, T. 2000. Future development in Portuguese rural areas: how to manage agricultural support for landscape conservation? Landscape and Urban Planning 50:95-106.

Pinto-Correia, T., and R. Jorge. 1996. Rural marginalization in Southern Portugal: farmers reactions to European policies and current land use changes. Pages 286-297 in R. H. G. Jongman, editor. Ecological and landscape consequences of land use change in Europe. ECNC publication series on Man and nature 2, Tilburg, The Netherlands.

Pinto-Correia, T., and J. Mascarenhas. 1999. Contribution to the extensification/intensification debate: new trends in the Portuguese montado. Landscape and Urban Planning 46:125-131.

Pinto-Correia, T., and W. Vos. 2004. Multifunctionality in Mediterranean landscapes: past and future. Pages 135-164 in R. Jongman, editor. The new dimensions of the European landscape. Wagenigen UR Frontis Series Volume 4, Springer, Dordrecht, The Netherlands.

Pires, A. 2000. A caprinicultura na Serra do Caldeirão. Pages 19-55 in Direcção Regional de Agricultura do Algarve, Associação IN LOCO, editors. Valorização da caprinicultura na Serra do Caldeirão. Universidade do Algarve, Faro, Portugal.

Piussi, P., and E. P. Farrell. 2000. Interactions between society and forest ecosystems: challenges for the near future. Forest Ecology and Management 132:21-28.

Plieninger, T., and M. Schaar. 2008. Modification of land cover in a traditional agroforestry system in Spain: processes of tree expansion and regression. Ecology and Society 13(2): 25. [online] URL: http: //www.ecologyandsociety.org/vol13/iss2/art25/.

Pons, J., and J. G. Pausas. 2006. Oak regeneration in heterogeneous landscapes: the case of fragmented Quercus suber forests in the eastern Iberian Peninsula. Forest Ecology and Management 231:196-204.

Puigdefábregas, J., and T. Mendizabal. 1998. Perspectives on desertification: western Mediterranean. Journal of Arid Environments 39:209-224.

Pulido, F. J., and M. Díaz. 2002. Dinámica de la regeneración natural del arbolado de encina y alcornoque. Pages 39-62 in F. Pulido, P. Campos, and G. Montero, editors. La gestión forestal de las dehesas. IPROCOR, Mérida, Spain.

Pulido, F. J., and M. Díaz. 2005. Regeneration of a Mediterranean oak: a whole-cycle approach. Écoscience 12:92-102.

Research Systems, editor. 2001. ENVI 3.4. Research Systems, Boulder, USA.

Rietkerk, M., and J. van de Koppel. 1997. Alternate stable states and threshold effects in semiarid grazing systems. Oikos 79:69-76.

Rindfuss, R. R., S. J. Walsh, B. L. Turner, J. Fox, and V. Mishra. 2004. Developing a science of land change: challenges and methodological issues. Proceedings of the National Academy of Sciences 
of the United States of America 101:13976-13981.

[online] URL: http://www.pnas.org/content/101/39 /13976.full.pdf+html.

Rushton, S. P., S. J. Ormerod, and G. Kerby. 2004. New paradigms for modelling species distributions? Journal of Applied Ecology 41:193-200.

Scheffer, M., W. Brock, and F. Westley. 2000. Socioeconomic mechanisms preventing optimum use of ecosystem services: an interdisciplinary theoretical analysis. Ecosystems 3:451-471.

Segura, A. M., M. Holmgren, J. J. Anabalón, and E.R. Fuentes. 1998. The significance of fire intensity in creating local patchiness in the Chilean matorral. Plant Ecology 139:259-264.

Serviço de Reconhecimento e Ordenamento Agrário (SROA). 1970. Carta de Solos de Portugal (esc. 1:50000). Secretaria de Estado da Agricultura, Lisboa, Portugal.

Sistema Nacional de Informação de Recursos Hidricos a (SNIRH). São Brás de Alportel (31J/01C), dados de base, temperatura do ar média mensal. [online] URL: http://snirh.pt/.

Sistema Nacional de Informação de Recursos Hidricos $b$ (SNIRH). Barranco do Velho (30J/01UG), dados de base, precipitação anual. [online] URL: http://snirh.pt/.

Soares, P., P. Carvalho, and M. Tomé. 1998. Agrosilvopastoral and agrisilvicultural systems in Portugal. Pages 24-33 in T. Pukkala, and K. Eerikäinen, editors. Proceedings of the meeting Modelling the growth of tree plantations and agroforestry systems in South and East Africa, 24-28 August 1998, Joensuu, Finland. Research Notes 80. Faculty of Forestry, University of Joensuu, Joensuu, Finland.

Trabaud, L. 1981. Man and fire: impacts on Mediterranean vegetation. Pages 479-521 in F. Di Castri and D. W. Goodall, editors. Ecosystems of the world 11. Mediterranean-type shrublands. Elsevier, Amsterdam, The Netherlands.

Vallejo, V. R., J. Aronson, J. G. Pausas, J. S. Pereira, and C. Fontaine. 2009. The way forward. Pages 235-245 in J. Aronson, J. S. Pereira, and J. G. Pausas, editors. Cork oak woodlands on the edge.
Ecology, adaptive management, and restoration. Society for Ecological Restoration International, Island Press, Washington, D.C., USA.

Vicente, A. M., and R. F. Alés. 2006. Long term persistence of dehesas. Evidences from history. Agroforestry Systems 67:19-28.

Westoby, M., B. Walker, and I. Noy-Meir. 1989. Opportunistic management for rangelands not at equilibrium. Journal of Range Management 42:266-274. 